\title{
Antibacterial activity of Punica granatum L. peels extracts against three common human wound pathogenic bacteria and formulation of topical ointment and hydrogel pharmaceutical forms
}
A.A.Al-Abdula ${ }^{1}$
M. Sabar Al-Lami ${ }^{2}$
${ }^{1}$ Department of Biology, College of Sciences, University of Basrah
${ }^{2}$ Department of Pharmaceutic, College of Pharmacy, University of Basrah

\begin{abstract}
$\underline{\text { Abstract }}$
Ethanolic and aqueous extracts of Punica granatum L. peels were prepared and tested for antibacterial activity against Escherichia coli and Pseudomonas aerogenosa as gram negative bacteria and Staphylococcus aureus as gram positive bacteria. The suitability of extracts for topical pharmaceutical preparations was attempted by formulation of extracts into simple ointment and hydrogel pharmaceutical dosage forms. The antibacterial activity was assessed by agar well diffusion method using four different concentrations for both extracts include $(100,10,1,0.1 \mathrm{mg} / \mathrm{ml})$. Ethanolic and aqueous extracts showed antibacterial activity against Staphylococcus aureus, with lowest inhibition zone of $12 \mathrm{~mm}$ at $0.1 \mathrm{mg} / \mathrm{ml}$. The same result was obtained for ethanolic extract against E. coli, whereas, aqueous extract showed $9 \mathrm{~mm}$ zone of inhibition. The lowest inhibition zone against Pseudomonas aerogenosa, was $10 \mathrm{~mm}$ at $0.1 \mathrm{mg} / \mathrm{ml}$ of ethanolic extract and $1 \mathrm{mg} / \mathrm{ml}$ of aqueous extract which showed resistance at $0.1 \mathrm{mg} / \mathrm{ml}$. From this it is concluded that both extracts have inhibitor effect on the growth of both gram positive and negative bacteria and ethanolic extracts exhibited higher degree of antibacterial activity as compared to aqueous extract. In present study, simple ointment containing $(10 \% \mathrm{w} / \mathrm{v})$ of ethanolic extract and hydrogel containing $(10 \% \mathrm{w} / \mathrm{v})$ of aqueous extract were prepared successfully.
\end{abstract}

$\underline{\text { الخلاصة }}$

تم تحضير مستخلص كحولي ومائي من قشور نبات الرمان واختبرت فعاليته الحيوية باستخدام جراثيم سالبة لصبغة كرام منل Escherichia Pseudomonas aerogenosa coli المستحضرات الصيدلانية الخارجية الاستعمال على شكلي المرهم البسيط والجيل المائي. حددت فعالية المستخلصات تجاه الجراثيم باستخدام طريقة الحفر

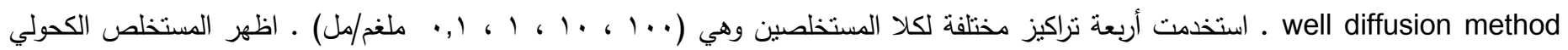

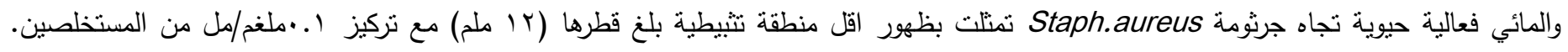

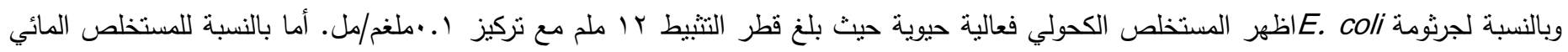

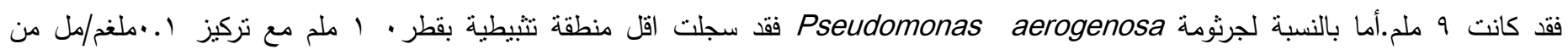

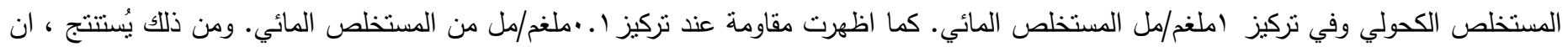
كلا المستخلصين أعطى نتائج تثيطية جيدة على نمو الجراثيم الموجبة والسالبة لصبغة كرام وكان المستخلص الكحولي أكثر فعالية من المستخلص المائي تم في هذه الدراسة تحضير مرهم بسيط بتركيز (10\% w/v w/v) من المستخلص الكحولي وتحضير جيل مائي بنركيز المستخلص المائي. بنجاح. 


\section{Introduction}

Many hundreds of plants worldwide are used in traditional medicine as treatments for different kinds of diseases, including bacterial infections. An antimicrobial is a substance that kills or inhibits the growth of micro-organisms such as bacteria, fungi, protozoan, etc. On the basis of mode of action, antimicrobials are classified into two broad categories as microbicidal that kill microbes without leaving any option for their survival and microbistatic that cease all the metabolic activities of microbes than are important for their survival so they are called as growth inhibitors of microbes (Khan and Hanee, 2011). Medicinal plants have been found useful in the cure of a number of diseases including bacterial infections. Medicinal plants are considered a rich source of antimicrobial agents (Mahesh and Satish, 2008). The concept of developing drugs from plants used in indigenous system is much older, while in some cases direct links between a local and biomedical use exists, in other cases the relationship is much more complex (Heinrich and Gibbons, 2001). Wound and particularly chronic wounds are major concerns for patients and clinical alike, chronic wounds affect a large number of patients and seriously reduce their quality of life. Balick and Cox (1996) reported that only 1-3\% of drugs listed in Western pharmacopoeia are intended for use in the skin and for wounds, by comparison, at least one third of herbal remedies are prepared for such use. Punica granatum Linn. has been widely used as traditional medicine in America, Asia, Africa and Europe for the treatment of different types of diseases (Lamar et.al, 2008; Kim et.al, 2002; Gracious et.al, 2001 and Murthy et.al, 2001). It has been highlighted in many studies as having antimicrobial activity against a range of both Gram positive and negative bacteria (Navarro et.al, 1996). Punica granatum L. , is commonly called pomegranate belong to the Punicacea family, is a large deciduous shrub or small tree. Pomegranate peel is a rich source of tannins, flavonoids, polyphenols and some anthocyanins as delphinidins, cyanidins, etc. ( $\mathrm{Li}$ et.al, 2006). The plant is used in folklore medicine for the treatment of various diseases, such as ulcer, dysentery, hepatic damage, snakebite, the plants has also been used as an antispasmodic and antihelmintic and its shows high antioxidant and antiarthergenic activity (Gopinath et.al, 2011 ;Lansky and Newman, 2007 and Aviram et.al, 2000).
Aim:- Evaluated in-vitro activity of Punica granatum L. peels extracts against some bacterial species like Staphylococcus aureus, Escherichia coli and Pseudomonas aerogenosa, which isolated from wound infection. The study was also designed to formulate the extracts into simple topical pharmaceutical dosage forms of ointment and hydrogel.

\section{Materials and methods}

Collection and extraction of plant material:Pomegranate were collected from a local market in Basrah city (November 2012). Peels were cut into smaller pieces and then washed with tap water followed by distilled water. The clean pieces were then dried under sunlight. The dried peels were then taken for grinding by household grinder. The powder was used for extraction.

\section{Extraction procedure}

Aqueous extract:- $5 \mathrm{gm}$ of pericarp powdered is added to $50 \mathrm{ml}$ of hot boil water for one hour at $70^{\circ} \mathrm{C}$. The extract was then filtered on WhatmanNo.1 filter paper and kept in hot air oven for drying. Then, the dried extract was dissolved in distilled water to produce solution with a concentration of $500 \mathrm{mg} / \mathrm{ml}$ (Khan and Hanee , 2011).

Ethanol extract:- $5 \mathrm{gm}$ of dried powder was soaked in $50 \mathrm{ml}$ of $70 \%$ (v/v) ethanol in tightly closed container in dark place in lab temperature for 3-4 days, mixture was then filtered. The filtrate was transferred on glass Petridish and left to dry in hood for two days. The dried extract was suspended in DMSO (dimethyl solphoxide) to make a final concentration of $500 \mathrm{mg} / \mathrm{ml}$ (Khan and Hanee, 2011).

Bacterial isolates:- Bacterial isolates used in this study were taken from wound infection in Al-Sadr education hospital, isolates included, Staphylococcus aureus, Escherichia coli and Pseudomonas aerogenosa . The isolates were confirmed by cultural and biochemical tests and maintained in nutrient agar slants at $4^{\circ} \mathrm{C}$ for antibacterial study.

Serial dilution preparation:- Serial dilutions were prepared with different concentrations of ethanolic and aqueous extracts $(100,10,1,0.1 \mathrm{mg} / \mathrm{ml})$ (Collee et al, 1996). 


\section{Screening of the extracts for antibacterial} activity:- Antibacterial activity was assessed by agar well diffusion method of Kirby Bauer wherein nutrient agar plates were prepared and spread with $20 \mathrm{ul}$ of the available pathogenic cultures. Wells of $5 \mathrm{~mm}$ diameter were bored using sterile borer. Wells were loaded with antimicrobial, (DMSO) and distilled water as control . Cultures were incubated at $37^{\circ} \mathrm{C}$ for 24 hours.

Formulation of the extracted products into topical:-pharmaceutical dosage forms:-The extracted products were formulated into simple topical pharmaceutical dosage forms of ointment and hydrogel, containing $10 \%(\mathrm{w} / \mathrm{v})$ of the extracts. The alcoholic extract was prepared in a form of an ointment while water extract was prepared in a form of hydrogel.

Ointment preparation:-The simple ointment containing alcoholic extract was prepared using incorporation method with a molten base of petroleum jelly. The extract was mixed within a previously molten base at $40^{\circ} \mathrm{C}$ over a hotplate, and then small volume of methanol was added to the mixture in order to dissolve the extract. Upon evaporation of methanol with continuous mixing using spatula a uniform and homogenized ointment was obtained and refrigerated (Allen et.al, 2011).

Hydrogel preparation:- A 10\% (w/v) Hydroxy propyl methyl cellulose (HPMC-grade E10M) gel according to a modified method of the Dow technical handbook (Dow, 2002) by gradual addition of HPMC powder with continuous gentle mixing using overhead stirrer (to avoid air trapping) into about $90 \%$ of the final volume of distilled water at a constant temperature of $90^{\circ} \mathrm{C}$ using a hot plate. A uniform dispersion system was obtained. The water extract was then dissolved in the mixture. The prepared mixture was cooled down though rapping the container with wet and cold tissue. When the temperature was dropped to around $70^{\circ} \mathrm{C}$, the final volume was made up by addition of distilled water with a gentle stirring until the temperature dropped to about $20^{\circ} \mathrm{C}$. The viscosity of product was increased and once capable of supporting the dispersion, the stirring was discontinued and the product was refrigerated at $5^{\circ} \mathrm{C}$ for $24 \mathrm{hr}$ to complete hydration and solubilization of HPMC.

\section{Results}

The present study, results showed that aqueous and ethanolic extracts from peels of Punica granatum L. inhibited the growth of both gram positive and negative bacteria including Staphylococcus aureus, Escherichia coli and Pseudomonas aerogenosa.The lowest inhibition zones with ethanolic and aqueous extracts were observed at $0.1 \mathrm{mg} / \mathrm{ml}$ for Staphylococcus aureus as shown in fig(1) and fig(2).

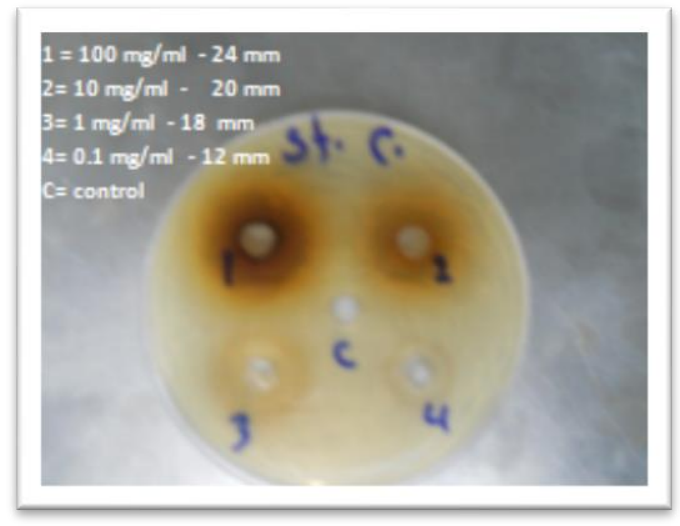

Fig (1) Antibacterial of ethanolic extract against Staph.aureus

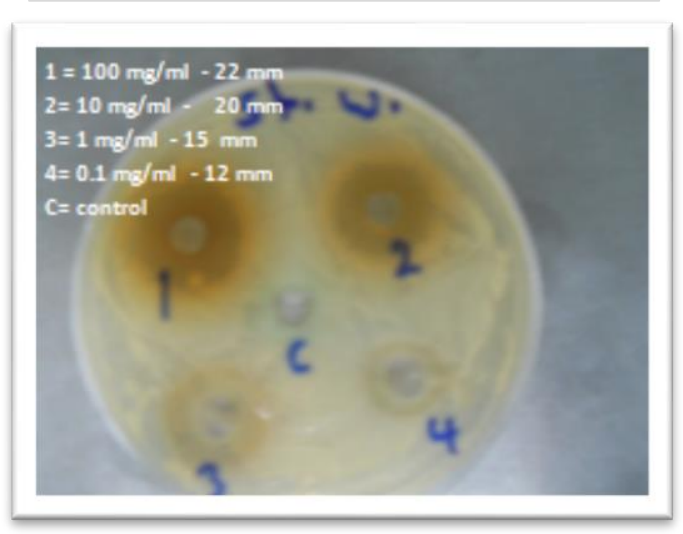

Fig (2)Antibacterial of aqueous extract against Staph.aureus

For E. coli, the lowest inhibition zones with ethanolic and aqueous extracts were observed at $0.1 \mathrm{mg} / \mathrm{ml}$ as shown in fig(3) and fig(4).

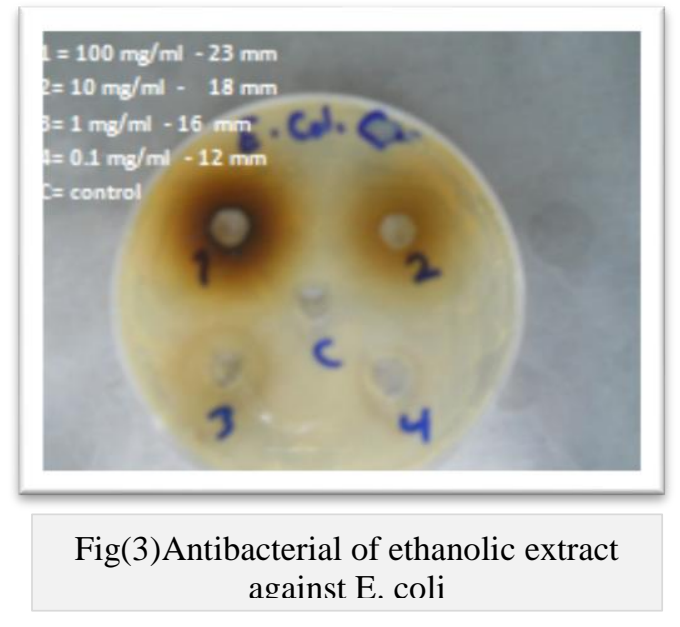




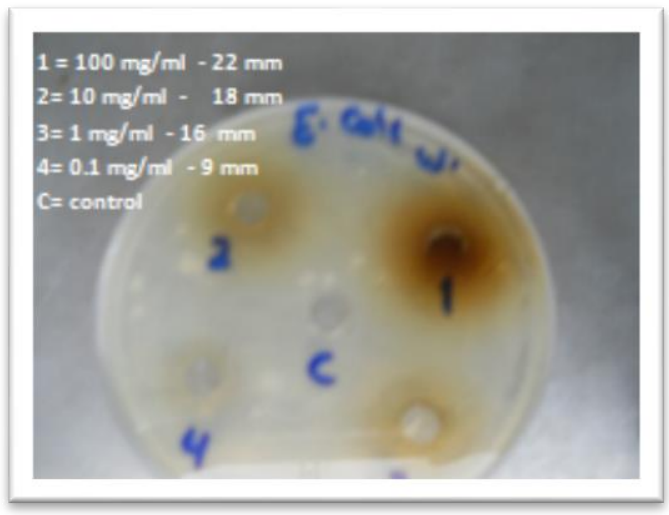

Fig(4)Antibacterial of aqueous extract against E. coli

For Pseudomonas aerogenosa, the lowest inhibition zones with ethanolic extracts were observed at $0.1 \mathrm{mg} / \mathrm{ml}$, while with aqueous extracts was at $1 \mathrm{mg} / \mathrm{ml}$. Pseudomonas aerogenosa showed resistance at the concentration of $0.1 \mathrm{mg} / \mathrm{ml}$ of aqueous extracts as shown in fig(5) and (6).

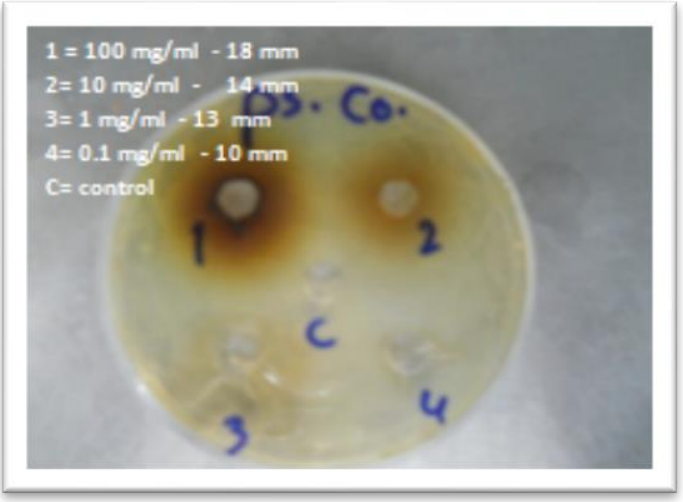

Fig (5)Antibacterial of ethanolic extract against $P$. aerogenosa

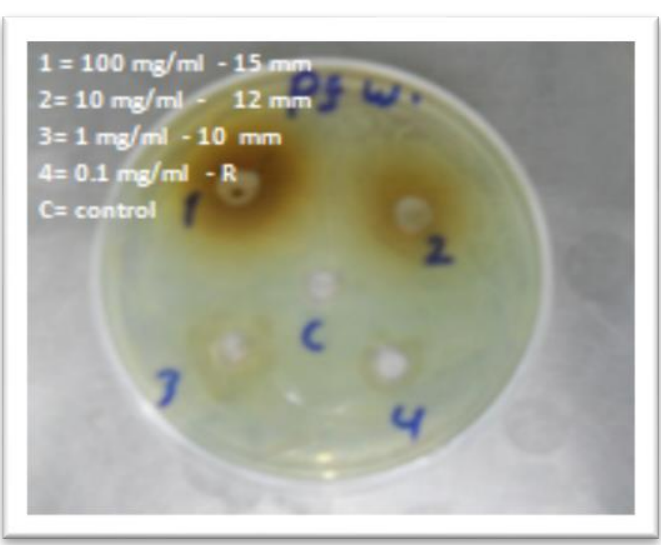

Fig (6)Antibacterial of aqueous extract against $P$. aerogenosa
Table (1) and (2) show inhibition zones with concentration of ethanolic and aqueous extract on Staphylococcus aureus, Escherichia coli and Pseudomonas aerogenosa .

Table (1):- Inhibition zone for ethanolic extract on tested bacteria

\begin{tabular}{|c|c|c|c|c|}
\hline \multirow{2}{*}{ Bacteria } & \multicolumn{4}{|c|}{ Concentrations of ethanolic extract } \\
\hline & $100 \mathrm{mg} / \mathrm{ml}$ & $10 \mathrm{mg} / \mathrm{ml}$ & $1 \mathrm{mg} / \mathrm{ml}$ & $0.1 \mathrm{mg} / \mathrm{ml}$ \\
\cline { 2 - 5 } & \multicolumn{4}{|c|}{ Inhibition Zone (mm) } \\
\hline Staph. aureus & 24 & 20 & 18 & 12 \\
\hline E.coli & 23 & 18 & 16 & 12 \\
\hline $\begin{array}{c}\text { Pseudomonas } \\
\text { aerogenosa }\end{array}$ & 18 & 14 & 13 & 10 \\
\hline
\end{tabular}

Table (2):- Inhibition zone for aqueous extract on tested bacteria

\begin{tabular}{||c|c|c|c|c|}
\hline Bacteria & \multicolumn{4}{|c|}{ Concentrations of aqueous extract } \\
\hline & $100 \mathrm{mg} / \mathrm{ml}$ & $10 \mathrm{mg} / \mathrm{ml}$ & $1 \mathrm{mg} / \mathrm{ml}$ & $0.1 \mathrm{mg} / \mathrm{ml}$ \\
\cline { 2 - 5 } & \multicolumn{4}{|c|}{ Inhibition Zone (mm) } \\
\hline Staph. aureus & 22 & 20 & 15 & 12 \\
\hline E.coli & 22 & 18 & 16 & 9 \\
\hline $\begin{array}{c}\text { Pseudomonas } \\
\text { aerogenosa }\end{array}$ & 15 & 12 & 10 & $\mathrm{R}$ \\
\hline \hline
\end{tabular}

In the current study, ethanolic extracts exhibited higher degree of antibacterial activity as compared to aqueous extract tested against bacteria. The extracted products were formulated into simple topical pharmaceutical dosage forms of ointment and hydrogel successfully. The alcoholic extract was prepared in a form of ointment while water extract was prepared in a form of hydrogel as shown in fig(7) .

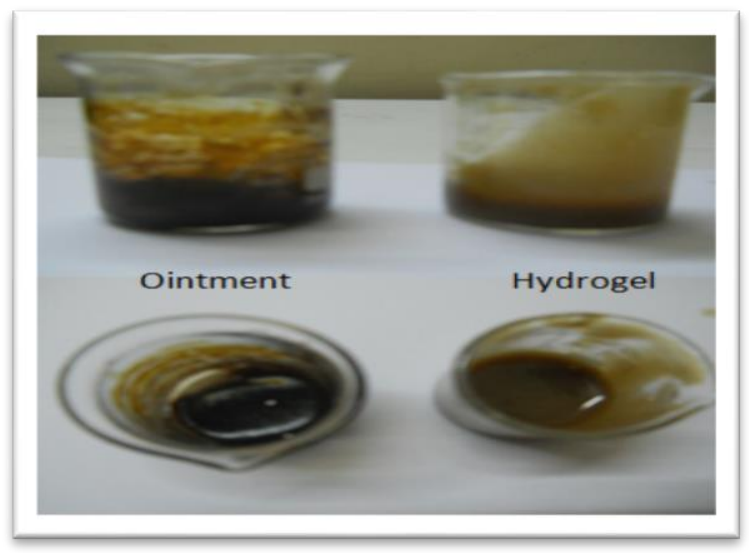

Fig (7) pharmaceutical forms of ointment and hydrogel containing $10 \%(\mathrm{w} / \mathrm{v})$ of extract of Pomegranate peel 
The suitability of ointment and hydrogel as pharmaceutical preparation for external use because isolates were from wound infection.

\section{Discussion}

Infectious diseases are disorders caused by pathogenic microorganisms like bacteria, fungi, protozoa and multicellular parasites. Infectious diseases account for about half of the deaths in tropical countries (Khosravi and Behzadi, 2006). Millions of bacteria normally live in the intestine, on the skin and the genitalia. Antibiotic resistance has become a global concern in recent years. This problem is of great significance especially in developing countries because infectious diseases are one of the major causes of mortality in these countries.Nearly, $80 \%$ of the world populations depends on the traditional medicine for primary health care, mainly including the use of natural products (Sandhaya et.al, 2006).Medicinal plants have been found useful in the cure of a number of diseases including bacterial diseases. Medicinal plants are a rich source of antimicrobial agents (Mahesh and Satish, 2008).Due to a rapid increase in the rate of infections, antibiotic resistance in the microorganisms and the side effects of synthetic antibiotics, medicinal plants are gaining popularity over these drugs (Babu and Subhasree, 2009). Although medicinal plants produce slow recovery, the therapeutic use of medicinal plant is becoming popular because of their lesser side effects and low resistance in microorganisms (Seyyednejad and Motamedi, 2010).Results obtained in the present study revealed that the tested plant, Punica granatum L extract possess potential antibacterial activity against Staphylococcus aureus, Escherichia coli and Pseudomonas aerogenosa that are isolated from wound infection. Punica granatum peel is a powerful astringent and cure for diarrhea, oral aphthae and suppression of inflammation and also has antioxidant activity (Lansky and Newman, 2007). In addition, it has antibacterial effect on Helicobacter pylori (Voravuthikunchai and Mitchlley, 2008), E. coli O157:H7 (Voravuthikunchai et.al, 2005). The investigation on Punica granatum peel showed that it contains both flavonoids and tannins a bundantly (Lansky and Newman, 2007).It appeared that the time period and temperature that used in extraction to ensure the complete isolation of bioactive agents (Khan and Hanee, 2011). The obtained results agreed with the study of Khan and Hanee, (2011) who found that the peels of Punica granatum extracted antibacterial activity against E. coli, Staphylococcus aureus and
Pseudomonas aerogenosa by using agar well diffusion method.Shahid et.al (2007), Supayang et.al (2005), Vasconalos et.al (2003) and Prashanth et.al (2001) mentioned that the peel extract contain tannins and phenolic acids of Punica granatum have antibacterial, antifungal and antiprotozoal activity. Many studies have shown that the pomegranate peel extract has wound healing properties (Chidambara et.al, 2002). Antibacterial activity (Prashanth et.al, 2001), antifungal activity (Dutta et.al, 1998) and antimicrobial effect (Navarro et. al, 1998).In the present study, it was clearly established that the ethanolic extract of pomegranate peel has better activity against both gram positive and negative bacteria, because ethanolic extract contains the antibacterial alkaloids. However, the aqueous extracts showed some activity that might be a result of tannins which are water soluble polyphenols that act as antimicrobial agents. Tannins are bacteriostaten because they prevent the development of microorganism by precipitating microbial proteins (Gopinath et.al, 2011).Many plants have been shown to possess therapeutic potential as promoters of wound healing and they possible played role by some prohealing phytoconstituents of the extract in the overall progression and contraction of the wound healing process previously implicated in wound healing processes (Odimegwu et al., 2008). A study of an attempt has been made by Martin and colleagues to formulate a cream containing alcoholic extract of pomegranate peel extract in two concentrations $(10 \%$ and $25 \%$ ) and concluded the formulated cream is dose dependent and the percentage transmittance of the cream reduced in the UV region when compared to other regions (martin et.al, 2011). Hayouni and collaborates have been conducted a study of formulation of $5 \%(\mathrm{w} / \mathrm{w})$ methanolic extract of Punica granatum peels based-ointment and evaluation of the prepared ointment for wound healing in guinea pigs and found that, the ointment significantly enhanced the wound contraction (Hayouni et.al, 2011).According to our results, we can conclude that Punica granatum peels extracted antibacterial activities against pathogens isolated from wound infection, and the Punica granatum extracts can be prepared as ointment and gel as antibacterial and to promote wound healing.

\section{Conclusion}

1- It is possible to prepared ethanolic and aqueous extract of Pomegranate peel. 
2- Pomegranate is found to be associated with antibacterial activities against gram positive and negative bacteria.

3- Ethanolic extract of pomegranate peel has higher activity than aqueous extract against both gram positive and negative bacteria more.

4- Ethanolic extract and aqueous extract are suitable to formulate ointment and hydrogel topical dosage pharmaceutical forms.

\section{Recommendation}

1- Further work on isolation and characterization of the bioactive compounds from the plant to evaluate other biological activities.

2- Further study may be required to quality the prepared dosage forms for pharmaceutical proprieties such as bio adhesion, and the release of therapeutic agents.

3- The evaluation of formulated ointment and hydrogel for skin repair and wound healing activity on experimental animals like guinea pigs or rabbit.

\section{Reference}

Aviram, M.; Dornfeld, L.; Rosenblat, M.; Volkova, N.; Kaplan, M.; Coleman, R.; Hayek, T.; Presser, D. and Fuhrman, B. (2000). Pomegranate juice consumption reduces oxidative stress, atherogenic modifications to LDL, and platelet aggregation: studies in humans and in atherosclerotic apolipoprotein E-dehxient mice. Am. J. Clin. Nutr. 71,1062-1076.

Allen, L.V.; Popovich, N.G. and Ansel, H.C. (2011). Ansels pharmaceutical dosage forms and drug delivery systems. 9th edn. Wolters Kluwer Health/Lippincott Williams and Wilkins: philadelphia.

Babu, P.D. and Subhasree, R. S. (2009). Antimicrobial activities of Lawsonia inermis - a review. Acad. J. Plant. Sci.; 2(4): 231-232.

Balick, M. and Cox, P.A. ( 1996). Plants, People and Culture: The Science of Ethnobotany. Scientific American Library, W.H. Freeman and Company, New York.

Chidambara, M.K.; Jayaprakasha, G.K. and Singh, R.P. (2002). Studies on antioxidant activity of pomegranate (punica granatum) peel extract using in vivo models. J. Agric. Food Chem.;14(50): 4791.

Collee, J. ; Fraser, A. ; Marmion , B. and Simon, A. (1996). Makie and Mc Cartney Practical Medical Microbiology. 14th edt. Churchill Liverstone. New York. 978 PP.

Dow. (2002). Methyl cellulose ethers technical hand book, company D (ed) Dowcompany.

Dutta, B.K.; Rahman, I. and Das, T.K. (1998). Antifungal activity of Indian plant extracts. Mycoses. 41: 11-12.

Gopinath, S. M.; Suneetha, T. B.; Mruganka, V. D. and Ananda, S. (2011). Chemical profiling and antibacterial activity of Punica granatum L. against pathogens causing Bovine Mastitis. J. Chem. Pharm. Res. 3(5): 514-518.

Gracious, R.R.; Selvasubramanian, S. and Jayasundar, S. (2001). Immunomodulatory activity of Punica granatum in rabbits: a preliminary study. J. Ethnopharmacol. 78: 85-7.

Hayouni, E.A.; Miled , K.; Boubaker, S.; Bellasfar, Z.; Abedrabba, M.; Lwaski, H.; Oku, H. and Matsui, T. (2011). Hydroalcoholic extract basedointment from Punica granatum L. Peels with enhanced in vivo healing potential on dermal Wounds. The free Library.

Heinrich, M. and Gibbons, S . ( 2001) . Ethnopharmacology in drug discovery: an analysis of its role and potential contribution..). Pharm. Pharmacol. 53, 425-430.

Khan, J.A. and Hanee, S. (2011). ANTIBACTERIAL PROPERTIES OF PUNICA GRANATUM PEELS. Inter. J. Appli. Biolog. and Pharmaceutic. Technolo. (2): 3.

Kim, N.D.; Mehta, R.; Yu, W.; Neman, I.; Livney, T.; Amichay, A.; Poirer, D.; Nicholls, P.; Kirby, A.; Jiang, W.; Mansel, R.; Ramachandran, C.; Rabi, T.; Kaplan, B. and Lansky, E. (2002). Chemopreventive and adjuvant therapeutic potential of pomegranate (Punica granatum) for human breast cancer. Breast Cancer Res. Tr. E. 71:203-17.

Lamar, A.S.; Fonseca, G.; Fuentes, J.L.; Cozzi, R.; Cundari, E.; Fiore, M.; Ricordy, R.; Perticone, P.; Degrassi, F. and Salvia, R.D. (2008). Assessment of the genotoxic risk of Punica 
granatum L . (Punicaceae) whole fruit extracts. J. Ethnopharmacol. 115:416-22.

Lansky, E.P. and Newman, R.A. (2007). Punica granatum (pomegranate) and its potential for prevention and treatment of inflammation and cancer, Review. J. Ethnopharmacology;109: 177-206

Li, Y.; Guo, C.; Yang, J.; Wei, J.; Xu, J. and Cheng, S. (2006). Evaluation of antioxidant properties of pomegranate peel extract in comparison with pomegranate pulp extract. Food Chem. 96:254260.

Machado, T.; Pinto, A.; Pinto, M.; Leal, I.; Silva, M.; Amaral, A.Kuster, R. and Netto dosSantos, K. (2003). In vitro activity of Brazilian medicinal plants, naturally occurring naphthoquinones and their analogues, against methicillin-resistant Staphylococcus aureus. Int. J. Antimicrob. Agents. 21:279-284.

Mahesh, B.; and Satish, S. (2008). Antimicrobial activity of some important medicinal plant against plant and human pathogens. World. J. Agric. Sci.; 4 (S): 839-843.

Martin, A.C.; Khan, G.R.; Narayanan, N.H.; Prabhu, M. and Vani P.(2011) . Evaluation of sun screening and antibacterial activity of extract. J. International of Pharma and Bio. Sciences.

Murthy, K.N.; Reddy, V.K.; Veigas, J.M. and Murthy, U.D. (2001). Study on wound healing activity of Punica granatum peel. J. Med. Food. 7: 256-59.

Navarro, V.; Villarreal, M.; Rojas, G. and Lozoya, X. (1998). Antimicrobial Evaluation of some plants used in Mexican traditional medicine for the treatment of infectious diseases .J. Ethnopharma. 53(3): 143.

Navarro, V.; Villarreal, M.L.; Rojas, G. and Lozoya, X. (1996). Antimicrobial evaluation of some plants used in Mexican traditional medicine for the treatment of infectious diseases. J. Ethnopharmacol. 53:143-47.

Odimegwu , D. C.; Ibezim , E. C.; Esimone , C. O.; Nworu , C. S. and Okoye, F.B.C. (2008). Wound healing and antibacterial activities of the extract of Dissotis theifolia (Melastomataceae) stem formulated in a simple ointment base $\mathrm{J}$. Medicinal Plant Res. 2(1); 011-016

Prashanth, D.; Asha, M. and Amit, A. (2001). Antibacterial activity of Punica granatum. Fitoterapia. 72:171-173.
Sandhaya, B.; Thomas, S.; Isabel, and Shenbargarathai, R. (2006). Ethnomedicinal plants used by the valaiyan community of piramalai Hills (reserved forest) ,Tamil Nadu, India, -A pilot study. African J. traditional, Complementary and Alternative Medicines.3: 101-14.

Shahid, I.; Hallem, S.; Akhtar, M. and Zia-W, H. A. J. (2007).J food res.,10-13.

Supayang, P.V.; Treechada, S.; Surasak, L.; Thanomjit, S.; Tetsuya, I. and Takeshi, H. (2005). Inhibitory effect of active compounds from Punica granatum pericarp on verocytotoxin production by enterohaemorrhagic Escherichia coli O 157: H 7: J. Health Science. 51: 590-596.

Vasconcelos, L.C.D.; Sampaio, M.C.C.; Sampaio, F.C. and Higino, J.S. (2003). Use of punicca granatum as an antifungal agent against candidosis associated with denature stomatitis. Mycoses. 46(5-6): 192-196.

Voravuthikunchai, S.p. and Mitchlle, H. (2008). Inhibitory and killing activities of medicinal plants against Multiole antibiotic resistant strains of H.pylori. J. Health science.;54(1):81-88

Voravuthikunchai, S.P.; Sririrak, T.; Limsuwan, S.; Supawita, T.; Iida, T. and Honda, T.(2005). Inhibitory effect of active compounds from Punica granatum Pericarp on verocytotoxin production by Enterohemorrhagic Escherichia coli O157: H7. J.Health Science.,; 51:590-596 